\title{
Foucault's Rhetorical Theory and U.S. Intelligence Affairs
}

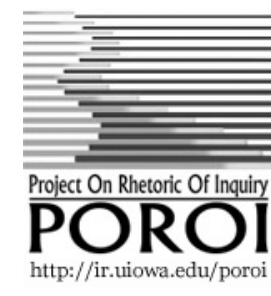

Hamilton Bean

Dept. of Communication, University of Colorado - Denver, Denver, CO, USA

Poroi 6, 2, January 2010

The September 11th, 2001 terrorist attacks on the United States sparked renewed interest from social scientific, rhetorical, and critical/cultural scholars in how communication theory can inform current intelligence and national security debates (Corman, Trethewey \& Goodall, 2008; Goodall, 2006; Hartnett \& Stengrim, 2004; Mitchell, 2002). The U.S. military shares this interest. Organizations including the CIA, the U.S. Air Force, and the National Defense Intelligence College have recently begun assessing and compiling elements of rhetorical theory that can be used to improve intelligence analysis (Bean, 2009; Mills, 2003; Woodward, 2009). Accordingly, in 2003, the Air University published an essay written by Air Force Major Gary H. Mills entitled: "The Role of Rhetorical Theory in Military Intelligence Analysis: A Soldier's Guide to Rhetorical Theory." In this essay, Major Mills argues that Michel Foucault's rhetorical theory "serves as a powerful militaryintelligence force multiplier" (p. xvii).

My aim is to understand the meaning, accuracy, and implications of Major Mills's statement. Toward this end, I first engage the literature surrounding Foucault's ideas concerning the interrelationships among power, knowledge, and discourse and review arguments in favor of connecting Foucault's ideas with rhetorical theory. I then analyze how Major Mills applies Foucault's ideas to the study of military intelligence analysis. I do this to assess whether his application makes good sense in light of existing scholarship concerning Foucault's relation to rhetoric. I then move beyond the specific case Major Mills provides to examine the broader implications of Foucault's ideas in relation to U.S. national security organizing. I conclude by summarizing the overall importance of these ideas for scholars and intelligence practitioners. 


\section{Foucault and Rhetoric}

Although Foucault rarely wrote or spoke about "rhetoric," the arguments in favor of connecting Foucault's ideas with rhetorical theory are well-established and wide-ranging (Biesecker, 1992; Bizzell \& Herzberg, 2001; Blair, 1987, 1995; Blair \& Cooper, 1987; Foss \& Gill, 1987; Hardy \& Phillips, 2004; Herzberg, 1991; Mills, 2003). According to Bizzell and Herzberg, "Though Foucault avoids talking about rhetoric, preferring discourse as his comprehensive term, his theory addresses a number of ideas that are central to modern rhetoric. He makes a powerful argument that discourse ... is epistemic [and] a form of social action" (Bizzell \& Herzberg, 2001, p. 1434). Bizzell and Herzberg note that Foucault also addresses issues of context and demonstrates how the "microphysics of power" reside in laws, regulations, texts, and architecture that not only affect, but form, individuals. Scholars have used Foucault's theories to address rhetorical problems involving not only the epistemology of the knowledge/power relation, but resistance, human choice, and freedom.

Despite the uptake of Foucault's ideas within the communication discipline, Biesecker (1992), Blair (1995), and Blair and Cooper (1987) also note a tension concerning the appropriateness of Foucault's theories to the study of rhetoric given his perceived diminution of the "self-determining subject" in favor of powerful "discursive formations." Blair argues that taking Foucault's ideas seriously requires questioning basic assumptions about rhetoric (1995). A Foucauldian perspective maintains, for example, that "interpreting a text provides little in the way of understanding how it performs in the world, and ... rhetors are multidimensional voices who speak their institutional situatedness as well as their minds" (Blair, 1995, p. 122). According to Blair, the concept of "institutional situatedness" is one of Foucault's major contributions to the study of rhetoric.

Before examining the concept of "institutional situatedness" in the context of U.S. intelligence, it will be useful to briefly elaborate Foucault's ideas concerning the interconnection between discourse, power, and knowledge. The "episteme," which Foucault later termed "discursive formation," is critical for understanding the relationship between these three concepts. A discursive formation is a pattern of statements which constitute a system of knowledge in a given historical era. A discursive formation can be thought of as a cultural code, structure, or framework for knowledge constituted within a body of discourse or discursive practices (Foss \& Gill, 1987, p. 387). Foucault's Discipline and Punish: The Birth of the Prison (1977) illustrates these interrelationships. The power of the penal system within Western society gives rise to a discourse of 
criminology. In turn, that power-laden and authoritative discourse allows the institutions of the penal system to define criminality and to perpetuate certain rules, roles, and practices. For Foucault, teasing out which came first, power, knowledge, or discourse is irrelevant. They are reciprocal.

\section{Sites of Intelligence}

In "The Formation of Enunciative Modalities," Chapter 4 of The Archeology of Knowledge, Foucault attempts to discover "the place from which [discourses] come" (Foucault, 1972, p. 50). Foucault's discussion in this chapter explains the concept of institutional situatedness that Blair identifies as being critical to Foucault's contribution to rhetoric (Blair, 1995). Specifically, in the beginning of the chapter, Foucault asks a fundamental question about discourse: "Who is speaking?" By this, Foucault means to draw attention to the status, sanction, and rights of speakers within a discursive formation. Foucault uses the example of nineteenthcentury doctors to illustrate this point. The status of the doctor is generally a rather special one in all forms of society and civilization; he is hardly ever an undifferentiated or interchangeable person. Medical statements cannot come from anybody; their value, efficacy, even their therapeutic powers, and, generally speaking, their existence as medical statements cannot be dissociated from the statutorily-defined person who has the right to make them (Foucault, 1972, p. 50). It is not difficult to see how this issue applies to institutional discourse within the U.S. intelligence and national security arena. Pronouncements about an adversary's military capabilities and intentions cannot come from just anyone. A sophisticated and hierarchical system of analyst education, training, vetting, promotion, and evaluation ensures that the "consensus" of the U.S. intelligence community carries authority and is understood by the president, national security advisors, and the public to be analogous with the "truth" as best as it can be known. The perception of intelligence analysis as an elite, insular, and objective activity must be cultivated in order to bolster both the legitimacy of intelligence and the exercise of presidential power.

In a related argument, Foucault explains in The Archeology of Knowledge the importance of institutional sites of discourse and the positioning of subjects in relation to various domains or groups of objects. By institutional sites, Foucault means the physical locations wherein discourse derives added legitimacy. In the case of nineteenth-century doctors, relevant institutional sites included the hospital, private practice offices, the laboratory, and medical libraries. During the nineteenth-century, the relative importance of 
these sites declined as developments in medical science, industry, and technology altered institutional dynamics.

The importance of institutional sites within the discourse of intelligence and national security is perhaps even greater than in the medical profession; only a handful of physical locations serve as legitimate sites of official intelligence discourse (i.e., CIA headquarters, the Defense Intelligence Agency, the National Security Agency, etc.). These sites influence, or perhaps constitute, a subject's ability to question, listen, see, observe, and use "instrumental intermediaries that modify the scale of ... information, shift the subject in relation to the average or intermediate perceptual level" (Foucault, 1972, p. 52). Foucault's discussion of the modalities of enunciation-utterability, speakability-helps us understand Blair's statement that "rhetors are multidimensional voices who speak their institutional situatedness" (1995, p. 122). Specifically, for Foucault, the emergence of clinical medicine (and other institutional discourses) cannot be simply regarded as a set of new practices resulting from changes in ideas or technologies. Instead, clinical medicine must be seen as the establishment of relations between a number of distinct elements including the status of doctors, institutional sites, and the subject's position. Foucault states, "I shall abandon any attempt, therefore, to see discourse as a phenomenon of expression-the verbal translation of a previously established synthesis; instead, I shall look for a field of regularity for various positions of subjectivity" (Foucault, 1972, p. 55).

The idea of institutional situatedness thus helps to explain how cultural and organizational context shapes subjectivity. The concept of "exteriority" complements this idea and extends it to "texts." Exteriority is the idea that a "text" (defined here as a relatively permanent inscription, especially of words) stabilizes or destabilizes a discursive formation rather than serving as a container of meaning. Put another way, exteriority "opposes the interpretation of a text and looks instead for the external conditions of its existence" (Herzberg, 1991, p. 73). The concept of exteriority is important within the study of intelligence and national security because, in one sense, intelligence texts (e.g., the President's Daily Brief or the National Intelligence Estimate) correspond to Foucault's assertion that authorial biography is a problematic interpretive device. This explains why there are no "by-lines" on the most influential intelligence "products." Foucault helps us understand how true it is that the institution of U.S. intelligence authors them.

The concepts of discursive formation, institutional situatedness, and exteriority point to two important aspects of power and 
knowledge. First, an actor is powerful only within a particular discursive context because discourse creates the roles from which power can be exercised (Hardy \& Phillips, 2004, p. 303). Second, rhetoric is epistemic, i.e., rhetoric creates knowledge rather than revealing preexisting and objective phenomena. For example, Foss and Gill, focusing on discursive practices, rules, roles, power, and knowledge to generate a "middle-level," theory of rhetoric as epistemic, apply this theory to the case of Disneyland in order to understand how Disneyland works as a discursive formation (Foss \& Gill, 1987). Foss and Gill's application of Foucault's theory to the case of Disneyland will later be shown in this essay to be useful for understanding how power, discourse, and knowledge converge within the national security arena. The point at present is that their treatment of Foucault's theories is similar to Major Mills's in that both seek to bring Foucault down from the realm of theoretical speculation to a level of concrete application. Bearing this in mind, we may now explore Major Mills's application of Foucault.

\section{Major Mills, Michel Foucault, and the Study of Military Intelligence Analysis}

"The Role of Rhetorical Theory in Military Intelligence Analysis: A Soldier's Guide to Rhetorical Theory" was published in 2003 by the Air University Press at Maxwell Air Force Base, Alabama. The Air University is a component of the Air Education and Training Command and is the Air Force's center for professional military education. In 2003, Major Mills was serving as a senior intelligence analyst at Supreme Headquarters Allied Powers Europe. He had previously served as an assistant professor of English at the United States Air Force Academy in Colorado Springs, Colorado. According to the Director of the Air University Library, the purpose of "The Role of Rhetorical Theory" is to "share Major Mills's rhetorical understanding with young officers attending initial intelligence training [and] a broader audience of traditional university students and instructors" (Mills, 2003, p. ix). Major Mills's essay is significant for two reasons. First, it has been promoted by the Air University as a "Fairchild Paper," which serves as a mark of distinction within the Air University system. Second, it is possibly the only publicly available document produced by the U.S. military that discusses the role of rhetorical theory, ancient, modern, or postmodern, within intelligence analysis (for a related discussion, however, see Keller \& Mitchell, 2006). The essay thus provides a window into the secretive world of intelligence analysis and suggests how rhetorical theory might be appropriated within that domain. 
Major Mills's essay contains eight chapters intersecting rhetorical theory with intelligence analysis. The central focus of the essay involves linking Foucault's theories of power and discontinuity to intelligence processes. The three chapters specifically covering Foucault's theories are entitled "[What the] Foucault?" "Power Plug," and "Discontinuity Fever." The text constructs Major Mills's military intelligence (and presumably masculine) audience as one inherently skeptical of rhetorical theory and Foucault's ideas. Here we reach one of my main points. Through bold assertions, Major Mills builds a counter ethos to Foucault that, ideally, allows Mills to circumvent the anticipated objections of his readers. For example, Major Mills states: "Foucault never served in the military; however, his firsthand occupation experience and painstaking study of history, human behavior, and-most importantly-power, made him a social and intellectual tactician of the highest order" (2003, pp. 21-22). Few readers would argue with Major Mills's observation that "underpinning the entire spectrum of conflict is a complex, evershifting flow of power, ruptures, and discontinuity" (p. 24). Nevertheless, Major Mills's incongruous attempt to "operationalize" Foucault's theories in the context of intelligence analysis creates problems. Mills himself acknowledges that "Foucault would frown upon this 'institutional' use of his power analysis," yet this situation does not prevent him from praising Foucault as a "very reluctant, unintentional military tactician” (pp. 22-23). Certainly, Foucault's ideas are open to wide interpretation. But Foucault's theoretical program was focused on social change. So, at its very core, Major Mills's application necessarily distorts aspects of Foucault's theories in order to make them amenable to preconceived intelligence doctrine.

For example, in Chapter 4, "[What the] Foucault," Major Mills introduces readers to Foucault's theories. He takes for granted that intelligence analysts will be unfamiliar with Foucault, and he tries to link basic Foucauldian concepts to core intelligence processes. He states, "Foucault understood the critical pivotal elements and practices of society: his most general aim was to 'discover the point at which these practices ... became coherent reflective techniques with definite goals ... and came to be seen as true"” (p. 23). This passage, like others quoted or cited from Foucault's work, is interpretively flexible. Elsewhere, Major Mills cites passages from Foucault that are downright incomprehensible. He acknowledges that readers will puzzle over such passages. As a result, he peppers his essay with reassuring tongue-in-cheek lines such as, "You may be asking, "What the Foucault?"' (p. 24). Despite the difficulty in understanding Foucault's concepts, however, Major Mills keeps 
enticing his readers: "Foucault can help you better understand the elusive human element of conflict-and the analysis of human struggles" (p. 25).

In Chapter 5, "Power Plug," Mills begins to apply Foucault's theory of power to intelligence analysis. "Since you are intelligence specialists," he states, "understanding the power in both your and the adversary's capabilities and systems is extremely critical" (p. 28). He largely ignores the role intelligence analysts themselves play in perpetuating the power of the national security apparatus, writing as though analysts were somehow able to observe and manipulate systems from a perch above them. He states, "It is difficult to use power effectively unless it is studied and observed from an appropriate vantage point. For Foucault, the vantage point starts at the 'panopticon'” (p. 28). Mills suggests that intelligence analysts are akin to the guards in Bentham's "panoptic prison," able to observe and control subjects from a central position. Foucault would presumably reject that analogy because it risks creating the perception that analysts themselves are somehow removed from the discourse in which operate. Major Mills thus acknowledges that the panopticon as he describes it is "not exactingly adapted by Foucault" (p. 29).

Nevertheless, Mills does acknowledge that "there are many operational panopticons in the military. Airborne command, control, and surveillance systems take their place as high-tech, mobile observation points" (p. 30). Major Mills cites a passage in The Archeology of Knowledge to link these military technologies to Foucault's ideas: “Thus, through spatial ordering, the panopticon brings together power, control of the body, control of groups, and knowledge" (p. 37). However, his discussion of power ultimately misses the importance of the panoptic gaze. The usefulness of the panopticon is not primarily in its ability to surveil multiple targets simultaneously. Its utility instead lies in producing self-regulation based on a perception (real or imagined) of continuous surveillance. Major Mills never addresses the contradiction wrought by the military's panoptic high-technology, i.e., massive increases in government surveillance of foreign countries, non-state actors, and one's own citizens has not led to corresponding reductions in U.S. security posture or armed conflict. Such technology has resulted, however, in sparking anxiety among citizens who are concerned that their every move might be monitored, recorded, and analyzed by government agencies (Der Derian, 1992).

Major Mills is more on the mark with his discussion of how the panopticon serves to "control the controllers" (p. 31): "From controlling who has information access through panoptic 
background investigations to centralized control of access mediums -message traffic, encrypted Internet Web sites, and compartmented programs-intelligence agencies carry many of the same watermarks of Bentham's original panopticon blueprint" ( $p$. 31). Mills is writing for an audience that may be reluctant to engage in critical self-examination. Therefore he quickly turns his attention from self-regulation to how Foucault helps to "magnify the oftenhidden power conduits in an adversary's structure" (p. 31, emphasis added). He abandons his scrutiny of the U.S. national security apparatus prematurely. So in the next section of this essay, I take up his examination with the help of rhetorical scholars who have articulated useful Foucauldian approaches to studying institutional discourses.

\section{Foucault and Force Enhancement}

Major Mills states that his purpose in writing "The Role of Rhetorical Theory" is "to share my widened rhetorical understanding with young officers attending initial intelligence training" (p. xiii). Major Mills claims, "For those who can see and wield it, theory serves as a force enhancement and a catalyst for powerful paradigm shifts" (p. xiv). Here, skillful "wielding” of rhetorical theory is promoted as a way to meet core institutional goals of analytical "effectiveness" and "quality." For Major Mills, the need for increased intelligence effectiveness and quality is clear. "The 11 September 2001 attacks on the World Trade Center and the Pentagon underscored a critical need to modify our understanding of the enemy point of view" (p. 55). Mills concludes that a better understanding of rhetorical theory can assist the intelligence community in its ability to "adapt and thwart failure," stating: "The end result of an enhanced understanding of theory is an adaptive intelligence organization that is able to provide a comprehensive view of the battle space to war fighters" (pp. 56-57).

Major Mills's essay can thus be interpreted as an artifact of the U.S. military's enduring pursuit of absolute control of the battlefield. This pursuit is represented in technocratic, "closedworld" discourse (Edwards, 1997). Contemporary examples of this discourse include "Total Battlefield Awareness" and "Joint Intelligence Preparation of the Operational Environment" with their seductive promises of "superior" knowledge and military dominance (Joint Chiefs of Staff, 2009). For Edwards (1997), "Closed-world discourse, through metaphors, techniques, and fictions as well as equipment and salient experiences, linked the globalist, hegemonic aims of post-World War II American foreign policy with a high-technology military strategy, an ideology of apocalyptic struggle, and a language of integrated systems" (pp. 7-8). Toward this end, Major Mills's essay attempts to enroll 
Foucault's rhetorical theory in support of a post-9/11 "technological utopia," i.e., "a chaotic and dangerous space rendered orderly and controllable by the powers of rationality and technology" (p. 72).

As a result, assertions such as, "Intelligence officers can excel as 'power boosters' and/or 'surge protectors' in order to maintain an optimal balance in the flow of "juice"' (p. 32) demonstrate Major Mills's lack of reflexivity. Mills avoids asking questions that might concern Foucault, such as:

1) For whom is the "flow of juice" optimally balanced?"

2) What are the defining discursive features and conditions of "optimal balance?" and most significantly;

3) What role does the discourse of intelligence play in perpetuating U.S.-led systems of domination and control?

Declarations such as, "If you can understand both your own and the adversary's discourse formation, you can better identify pivot points to reinforce, degrade, or attack" (p. 33) do not clearly point to the relevance of Foucault's ideas-intelligence analysts certainly do not need Foucault to tell them to "comprehend the enemy point of view" (p. 34) or beware "enemy deception" (p. 42).

Major Mills states in the Preface to "The Role of Rhetorical Theory," "I never fully grasped the rhetorical framework behind these critical modes of communication [intelligence] until I was exposed to discourse theory at the University of Arkansas at Little Rock" (xiii). He credits several "professional mentors" from the Department of Rhetoric and Writing in his acknowledgements. Despite his academic training, Major Mills provides a distorted application of Foucault's theories. Admittedly, the essay is written for an audience unfamiliar with Foucault's ideas. Nevertheless, the value of the essay for its target audience is questionable. Major Mills is correct when he states, "Obviously, our intelligence capabilities do not allow a complete, unhindered view of an adversary's discourse infrastructures" (p. 37). Given the complexity of Foucault's ideas, intelligence analysts and scholars alike ought to be wary of unelaborated assertions such as "If you can understand how to isolate, block, or manipulate the discourse flow of any weapons system, you have effectively removed it as a threat" (p. 37).

In Chapter 6, "Discontinuity Fever," Major Mills addresses the "complex shifts, ruptures, and discontinuities underlying the power structure" (p. 39). Major Mills never explicitly discusses what "discontinuity" means in the Foucauldian sense, but we can assume that he means that perceptions, descriptions, expressions, characterizations, and classifications rather suddenly change from 
one historical period to the next (Foucault, 1980). Mills's goal in this section is to explain the essence and mode of transformation of power relations and to consider how change can be viewed and analyzed with the help of a rhetorical lens. For example, he cites the death of Yugoslavian leader Marshal Tito in 1980 as an event that "created not only a power shift but a power rupture (creation of new power nodes) with innumerable discontinuities" (p. 40). Almost as an afterthought, he also states:

Iraq experienced a dramatic power shift in 2003. The regime change there opened many ruptures and discontinuities as this once repressed country gradually moves toward democracy. Observe the new power nodes that are established, modified, and removed as Iraq is returned to the control of its people (p. 40).

This passage is as disturbing for its silence regarding the role intelligence analysts themselves played in creating the "dramatic power shift" in Iraq in March 2003 as for its presumption about the direction in which change in Iraq will go. It is likely that at the time of the essay's publication in August 2003, Major Mills did not yet know how intelligence analysts had produced flawed assessmentsperpetuated and distorted by policymakers-leading to the invasion of Iraq under false pretenses (Hartnett \& Stengrim, 2006; Mitchell, 2006). Still, already emerging questions regarding the quality of the underlying intelligence supporting the case for "discontinuity" in Iraq may have nevertheless prompted Major Mills to warn his readers: "Suspicious gaps in collection, suspicious confirmations, and contradictions to carefully researched patterns represent discontinuities underscored as key warning signs [of enemy deception]" (p. 42).

In summary, the most significant flaw in Major Mills's treatment of Foucault is his failure to critically examine the role that intelligence analysts themselves play within the discursive system of national security. Analysts are not objective observers perched above discourse/power "conduits." As noted earlier, for Foucault, important questions about the production of knowledge were, "Who is speaking? What institutional role, legal status, social privilege, or educational or other certification determines who may claim the right to speak authoritatively" (Bizzell \& Herzberg, 2001, p. 1433)? In this sense, Major Mills's essay puts the cart before the horse: "Discourse is not the majestically unfolding manifestation of a thinking, knowing, speaking subject ... On the contrary, [it is] a totality, in which the dispersion of the subject and his discontinuity with himself may be determined" (Foucault, 1972, p. 55). Major Mills avoids directly addressing the implications of Foucault's project of "freeing the individual from the 'subjection' of particular knowledge systems and power relations that 'objectify' him/ 
her" (Blair, 1995, p. 129). To engage this issue head-on would undermine the very discursive system that generates the privileged roles that Major Mills and his fellow analysts occupy. In the next section, accordingly, I offer an alternative Foucauldian perspective on intelligence analysis that may shed more light on the interconnections between discursive practices and national security organizing than Major Mills evinces.

\section{The Broader Implications of Foucault's Theory for National Security}

Few would argue with Major Mills's motive: Any theory, rhetorical or otherwise, that helps protect innocent lives by anticipating or helping avoid armed conflict is worthy of application. However, the discussion above suggests that Major Mill's application of Foucault's theories is problematic. Major Mill's essay omits discussion of concepts that might help explain the role and function of intelligence analysts within the discursive system of U.S. national security. It is therefore necessary to supplement Major Mills's perspective in order to understand the implications of Foucault's theories for intelligence and national security organizing. Foss and Gill offer a useful supplement (Foss \& Gill, 1987). In their case study of Disneyland, the authors examine discursive practices, rules, roles, knowledge, and power in a way that compliments Major Mills's focus on power and discontinuity. Foss and Gill state that they selected Disneyland to illustrate Foucault's rhetorical theory because the "Magic Kingdom" constitutes a fully-developed system of discursive acts that result in truth and knowledge of a particular kind.

There are, in fact, concrete affinities and links between Disneyland and the U.S. national security apparatus when considered as discursive formations. For example, the Chief Scientist for the U.S. Director of National Intelligence from 2005 to 2007 was a former Executive Vice President at Walt Disney Imagineering. As reported by investigative journalist Lawrence Wright, the intelligence community turned to Walt Disney Imagineering to design the National Counter-Terrorism Center (NCTC) based in northern Virginia (Wright, 2009). As one former Disney executive at NCTC explained: "Even the chairs in the lunchroom are the same ones we had at the Disney Studios.... The only difference is these chairs don't have the mouse ears" (n.p.). Wright reports that several former Disney executives entered government service after the September 11, 2001 attacks: "The fantasy worlds that Disney creates have a surprising amount in common with the ideal universe envisaged by the intelligence community, in which environments are carefully controlled and people are closely observed, and no one seems to mind" (n.p.). 
Within Disneyland, Foss and Gill find that the design elements of the environment, the visitors' role, and the image of the employees constitute the major discursive practices (1987). These are oddly similar to discursive practices within the national security domain: 1) preference for elite, insider perspectives which rely on classified information; 2) the image and status of "intelligence" as a form of knowledge and an object of discourse; and 3) the role of policymakers within the "intelligence cycle." These discursive practices are reciprocal with national security rules, roles, knowledge, and power as explained below.

For Foucault, spatial design constitutes a discursive practice, and Foss and Gill highlight how the spatial elements within Disneyland regulate the flow and interaction of people. This spatially-oriented discursive practice within Disneyland has its counterpart within the U.S. intelligence community. Specifically, only those members of the intelligence community who have passed the requisite background investigations and polygraph tests are allowed to enter what is called a SCIF (Sensitive Compartmented Information Facility). SCIFs contain classified information necessary for producing intelligence assessments. ${ }^{i} \mathrm{SCIF}$ construction requirements ensure a regulated flow of authorized people within an intelligence agency or private contractor facility. The discourse surrounding SCIFs also reinforces the image of intelligence work as secret, elite, and valuable. Specifically, certain types of SCIFs require "a response force capable of responding to an alarm within 15 minutes after annunciation and a reserve response force available to assist the responding force" (Wieser, 2003). The spatial elements that regulate the flow of people within the intelligence system also mirror classification schemes which regulate the flow of information within the system.

Classification systems and compartmentalization create extreme secrecy within national security discourse. Foucault's critique of the "repressive hypothesis"-the hypothesis that power relations generally take the form of prohibition, censorship, or nonrecognition-suggests that this secrecy will have striking consequences from a rhetorical perspective. As Biesecker notes, Foucault alters the meaning of censorship by seeing in it not a ban on talk, but instead, a mechanism for an explosion of discourses (Biesecker, 1992, p. 353). Foucault's critique of the repressive hypothesis was in relation to sexuality. However, the same principles apply in the case of national security and, in addition, explain why intelligence generates an allure, creating an eager audience for spy movies, television programs, books, and news. This allure generates a certain cultural context and understanding 
of national security issues which, in turn, imbues intelligence analysis and policymaking. ${ }^{\text {ii }}$

The idea of "authenticity" offers another parallel between the discursive practices of Disneyland and the national security apparatus. In Disneyland, the design features are primarily synthetic. Omitted from the "frontiers," "jungles," or "waterways" are any natural occurrences that might offend customers (Foss \& Gill, 1987). Similarly, within the intelligence community, dialogue, interaction, and authentic understanding of foreign cultures are notoriously lacking (9-11 Commission, 2004; Commission on the Intelligence Capabilities, 2005). This fact is unsurprising given that classification schemes, spatial configurations, and institutional strictures inhibit interaction with foreign nationals. For example, the Commission on the Intelligence Capabilities of the United States Regarding Weapons of Mass Destruction (2005) indicated that the lack of authentic cultural understanding led, in part, to the intelligence community's failure to accurately assess the WMD threat that Iraq posed to the United States. iii Like Disneyland, discursive practices within the intelligence community reinforce inauthentic portrayals and limit the possibility of interaction with foreign nationals who might otherwise challenge institutional preconceptions.

Within Disneyland, the role of visitors is passive despite the interactivity depicted in the organization's publicity materials. Likewise, within the intelligence community, the mantra of "support the policymaker" obscures the fact that very few policymakers engage directly with the intelligence community. Most policymakers, similar to Disneyland patrons, are passive consumers. According to noted intelligence scholar and insider, Mark Lowenthal, intelligence consumers are presented with a largely standardized repertoire of intelligence products, i.e., "a set product line" (2006, p. 62). Policymaker feedback within this discursive system is rare.

Foss and Gill's reading of Foucault thus supplements Major Mills' and allows us to assess some of the broader implications of Foucault's theory for national security organizing. National security is a powerful discursive system that relies on antidemocratic, closed, and tightly regulated discourse to nominally protect the interests of the "American people." The discursive practices of intelligence classification and compartmentalization cloak intelligence analysis and national security policy in secrecy and reinforce their status as objects of discourse better left to national security elites and insiders-not citizens. The extreme seclusion of the typical intelligence analyst-from both foreign nationals and U.S. policymakers-constitutes a discursive practice that distorts 
analytical priorities and judgments which, in turn, distorts policymaking and public understanding. These discursive practices consistently generate power relations that promote secrecy, mistrust, and groupthink within this institution (WMD Commission, 2005). Finally, within Disneyland, surveillance is ubiquitous. Foss and Gill do not explicitly acknowledge that freedom of movement within its environs is permitted by one's participation in a comprehensive system of monitoring. In addition to the artifacts and experiences that Foss and Gill describe, surveillance contributes to practices that "embody rules and power relations that promote wholesome, sterile, and predictable behavior and that produce rhetors who fill passive, clean, unquestioning roles" (Foss \& Gill, 1987, p. 397). Here we might consider how the intelligence community's massive, high-tech effort to overtly and covertly intercept and monitor most of the world's electronic signals, in part, mimics Disneyland's goals and design.

\section{Conclusion: Foucault's Relevance to Rhetorical Studies}

Herzberg states that "scholars have cited Foucault dutifully as a powerful influence on modern epistemological skepticism, but he seems to have had little place in the classroom" (1991, p. 80). Thus, some may find Major Mills's attempt to pragmatically "operationalize" Foucault's theories in the context of military intelligence analysis laudable, but it is unlikely Foucault will become standard reading for analyst trainees anytime soon. Treating Foucault's rhetorical theory as a "powerful militaryintelligence force multiplier" ala Major Mills limits the theory's explanatory power in the case of intelligence and national security organizing. However, following Blair's (1987) contribution, scholars can make the following observations about Foucault's relevance to rhetorical theory, and by extension, to the study of intelligence and national security institutions.

First, for Foucault, an act of discourse is an act of power. The United States' power is, of course, measured in material (military and economic) strength, but its power also manifests in and through discursive (i.e., symbolic) hegemony. Second, engaging in national security affairs requires enacting discursive rules and roles. As a discursive system, national security requires intelligence analysts, officials, policymakers, threats, and numerous other discursive positions to be filled. Third, according to Blair, "It was Foucault's contention that we should examine the exterior of a statement, its relationship to other statements, rather than to look toward the statement's interior, its author's intended meaning" (1987, p. 378). This concept takes on new relevance in light of intelligence failures preceding the 2003 Iraq War. We may 
learn more about the workings of national security discourse/ power/knowledge by looking at a text in relation to public statements made by top administration officials than by looking "inside" the text itself. Fourth, discourse is contextual and contingent. The same words may be repeated by the same speaker to the same audience yet constitute different meanings.

Blair notes that the list of Foucault's contributions to rhetoric could be taken much further, and the same can be said for his potential contributions to the study of U.S. national security organizing (1987, p. 379). The connection between Foucault's theories, rhetoric, and intelligence and national security institutions provide scholars with an engaging set of problems. Viewed as the interplay among institutional knowledge, power, and discourse, communication scholars interested in studying intelligence and national security can easily find Foucault's sanction. Application of Foucault's theories within this arena remains a challenging opportunity yet to be further explored.

(C) Hamilton Bean, 2010.

\section{References}

9-11 Commission. (2004). Final report of the national commission on terrorist attacks upon the United States. Available from http://www.9-11commission.gov/.

Bean, H. (2009). Communication and intelligence: Allies or enemies? International Journal of Intelligence and CounterIntelligence, 22, 360-365.

Biesecker, B. (1992). Michel Foucault and the question of rhetoric. Philosophy and Rhetoric, 25, 350-364.

Bizzell, P., \& Herzberg, B. (Eds.). (2001). The rhetorical tradition: Readings from classic times to the present. Boston, MA: Bedford/St. Martin's, 1432-1470.

Blair, C. (1987). The statement: Foundation of Foucault's historical criticism. Western Journal of Speech Communication, 51, 364-383.

Blair, C. (1995). Symbolic action and discourse: The convergent/ divergent views of Kenneth Burke and Michel Foucault. In B. L. Brock (Ed.), Kenneth Burke and contemporary European thought: Rhetoric in transition. Tuscaloosa, AL: University of Alabama Press, 119-165.

Blair, C., \& Cooper, M. (1987). The humanist turn in Foucault's rhetoric of inquiry. Quarterly Journal of Speech, 73, 151-171.

Commission on the intelligence capabilities of the United States 
regarding weapons of mass destruction. (2005). Report to the President of the United States. Available from http:// www.gpoaccess.gov/wmd .

Corman, S. R., Trethewey, A., \& Goodall, H. L. (Eds.). (2008). Weapons of mass persuasion: Strategic communication to combat violent extremism. New York: Peter Lang Publishing.

Der Derian, J. (1992). Antidiplomacy: Spies, terror, speed, and war. Cambridge, MA: Blackwell.

Edwards, P. N. (1997). The closed world: Computers and the politics of discourse in cold war America. Cambridge, MA: The MIT Press.

Foss, S., \& Gill, A. (1987). Michel Foucault's theory of rhetoric as epistemic. Western Journal of Speech Communication, 51, 384-401.

Foucault, M. (1972). The archeology of knowledge and the discourse on language. trans. A. M. Sheridan Smith. New York: Pantheon Books.

Foucault, M. (1977). Discipline and punish: The birth of the prison. trans. A. Sheridan. New York, NY: Pantheon.

Foucault, M. (1980). Power/Knowledge: Selected interviews \& other writings 1972-1977. C. Gordon (Ed.). New York, NY: Pantheon.

Goodall, H. L. (2006). Why we must win the war on terror: Communication, narrative, and the future of national security. Qualitative Inquiry, 12, 30-59.

Hardy, C., \& Phillips, N. (2004). Discourse and power. In D. Grant, C. Hardy, C. Oswick, \& L. Putnam (Eds.), The Sage handbook of organizational discourse (pp. 299-316). London, Sage.

Hartnett, S. J., \& Stengrim, L. A. (2004). 'The whole operation of deception:' Reconstructing President Bush's rhetoric of weapons of mass destruction. Cultural Studies Critical Methodologies, 4, 152-197.

Herzberg, B. (1991). Michel Foucault's rhetorical theory. In P. Harkin \& J. Schilb (Eds.). Contending with words: Composition and rhetoric in a postmodern age. New York, NY: MLA, 69-81.

Joint Chiefs of Staff (2009). Joint publication 2-01.3: Joint intelligence preparation of the operational environment. Available from: http://www.dtic.mil/doctrine/index.html. 
Keller, W. W., \& Mitchell, G. R. (Eds.). (2006). Hitting first:

Preventative force in U.S. security strategy. Pittsburgh:

University of Pittsburg Press.

Lowenthal, M. (2006). Intelligence: From secrets to policy (3rd ed.). Washington, DC: CQ Press.

Mills, G. H. (2003). The role of rhetorical theory in military intelligence analysis: A soldier's guide to rhetorical theory. Fairchild Paper Series. Maxwell AFB, AL: Air University Press.

Mitchell, G. R. (2002). Public argument-driven security studies. Argumentation \& Advocacy, 39, 57-71.

Mitchell, G. R. (2006). Team B intelligence coups. Quarterly Journal of Speech, 92, 144-173.

Wieser, C. L. (2003). Sensitive compartmented information facilities. Briefing prepared for the Western Region Security Office. Available from www.wasc.noaa.gov/wrso/briefings/ Scif.ppt

Woodward, N. Preaching truth to power: Toward a rhetorical framework of intelligence analysis. Unpublished masters thesis, National Defense Intelligence College, Washington, DC, 2009.

Wright, L. (2008, January 21). The spymaster: Can Mike McConnell fix America's intelligence community? The New Yorker. Available from: http://www.newyorker.com/ reporting/2008/01/21/080121fa_fact_wright 
ii Formally, a SCIF is defined as "an accredited area, room, group of rooms, buildings, or installation where SCI (Sensitive

Compartmented Information) may be stored, used, discussed, and/ or processed" (Wieser, 2003).

ii For a detailed discussion of this process, see James Der Derian's Antidiplomacy: Spies, Terror, Speed, and War (1991).

iii The Commission Report states: "The October 2002 NIE [National Intelligence Estimate] contained an extensive technical analysis of Iraq's suspected weapons programs but little serious analysis of the socio-political situation in Iraq, or the motives and intentions of Iraqi leadership-which, in a dictatorship like Iraq, really meant understanding Saddam. It seems unlikely to us that weapons experts used to combing reports for tidbits on technical programs would ever have asked: 'Is Saddam bluffing?' or 'Could he have decided to suspend his weapons programs until sanctions are lifted?' But an analyst steeped in Iraq's politics and culture at least might have asked those questions, and, of course, those turn out to be the questions that could have led the Intelligence Community closer to the truth." 